\title{
Un hombre que hacía claro lo obscuro
}

$\mathrm{A}^{\mathrm{L}}$ Instituto Internacional de Literatura Iberoamericana 1 dedica este número de su revista a honrar la memoria de Pedro Henríquez Ureña a diez años de su muerte, y a revivir la huella de su enseñanza y su labor crítica en las varias tierras en que cumplió su trayectoria. Entre ellas una de las más vecinas es Venezuela, no porque haya vivido en nuestro país, sino por el conocimiento afectuoso y próximo que le merecieron, especialmente en su juventud, letras y hombres venezolanos. En algunos diálogos con él, en Buenos Aires, le escuché evocar aquella andariega colonia venezolana que en los últimos días del siglo XIX y primeros del presente - de modo muy concreto bajo la dictadura de Cipriano Castro- visitó Santo Domingo y le dieran a conocer, entre otras cosas, ese capítulo tan importante del Modernismo literario en Hispanoamérica que se difundió desde la revista El Cojo Ilustrado. Entre rostros de políticos, barbados generales del $1900 \mathrm{y}$ bachilleres anti-castristas, recordaba don Pedro que visitaron entonces su legendaria Quisqueya algunas hermosas y vivacísimas mujeres venezolanas por quienes todavía me interrogaba en Buenos Aires y en perspectiva nostálgica de cuarenta y tantos años. ¿Qué fue de aquellas damas de madrigal; qué de sus bellezas y tocados? Yo respondí a don Pedro que las había conocido abuelas.

En un ensayo juvenil escrito en 1905, Henríquez Ureña cita entre los tres prosistas más importantes de la América Latina de aquellos días a dos venezolanos: Manuel Díaz Rodríguez y César Zumeta. El otro de la ilustre trilogía a que le vaticinaba influencia más duradera, se llamaba José Enri- 
que Rodó. Y por nuestro siglo XIX - tan mal conocido fuera de las fronteras venezolanas - transitaba con sabiduría y fineza crítica a través de la obra de humanistas y poetas románticos como Juan Vicente González, Fermín Toro, Cecilio Acosta, José Antonio Calcaño o Juan Antonio Pérez Bonalde. No es preciso mencionar la obra de Bello que dominaba y conocía en toda su vasta órbita filosófica y filológica. Aun sobre el espiritu venezolano formulaba allá por el año 30 la teoría de que habiendo tenido Venezuela magisterio continental en los días de Bello y Bolívar y producido después escritores de alta significación, se opacó y agostó bajo la dictadura de Juan Vicente Gómez cuando se cerraron al país los movidos horizontes de la vida moderna. Pero celebró el final de aquella tiranía que auguraba, acaso, el renacer de nuestra mejor tradición literaria.

En más de una conversación con Henríquez Ureña y socorrido con los datos de su memoria, se me ocurría aventurar todo un capítulo - aun no bien formulado- de nuestra tradición intelectual. Fue el fulgurante contagio que tuvieron las ideas y movimientos de Venezuela en todo el mundo antillano del siglo XIX, cuando las colonias insulares vieron en nuestra guerra de Independencia paradigma y ejemplo grandioso; cuando Núñez de Cáceres, por ejemplo, quería negociar con Bolívar la liberación de su isla. Si el recuerdo de nuestra epopeya estuvo siempre presente en los sueños de un José María Heredia, el poeta cubano; si dimos a Cuba un aventurero heroico como Narciso López, no menos se pensaba en el estímulo de Venezuela durante la independencia de Santo Domingo en 1844. Hubo todo un camino de relaciones espirituales entre nuestra tierra y esa amada Quisqueya de Henríquez Ureña, que jamás se había interrumpido. Así los escritores y poetas modernistas dominicanos como Fiallo y Cestero se revelaron, también, en las páginas de El Cojo Ilustrado y publicaron li.bros en Caracas, como la diáspora frecuente de políticos, periodistas, o simples inconformes, pasaba de uno a otro país.

Pero esto eran sólo anécdotas que nos acercaban a la humana intimidad de Henríquez Ureña, cuya obra - sólo por haber vivido menos- no fue tan extensa como la de don Andrés Bello. La mente clara y organizadora, la riqueza y variedarl 
de sus disciplinas intelectuales, el gusto de sistematizar cuanto estaba disperso, parecen acercarlos como miembros de una misma familia espiritual. Era don Pedro, de cierto modo, un continuador de la obra de Bello con la natural frontera de métodos y sensibilidad de sus distantes generaciones. $\mathrm{Y}$ se ha perfilado en la vida intelectual hispanoamericana de nuestros días, predominantemente en la historia y crítica literaria y el análisis filológico, una tradición creada por el magisterio de Henríquez Ureña comparable a la que Bello suscitó en el siglo XIX. Ambos fueron maestros viajeros, y lo que decían en sus coloquios y sus clases tenía tanta sustancia y novedad como lo que estamparon en sus libros.

$\mathrm{Y}$ aun algo más: es curioso que dos hijos del trópico, tierra que según el mal determinismo geográfico de los positivistas, estaba abocada al desorden mental frente a la disciplina y el método que se atribuye a los climas fríos, representaran en distintos momentos de la cultura hipanoamericana, la más válida aspiración ordenadora. Porque había en ambos la voluntad goethiana de "hacer claro lo obscuro", de llevar a sistema y jerarquía los valores de nuestra tradición espiritual, de enlazarlos con los grandes movimientos del mundo y organizar una conciencia de América que asimile el pasado pero incorpore, asimismo, toda fuerza de renovación. Ambos luchan por la propiedad con que se use, de México a Argentina, la lengua española como indispensable instrumento unificador, mas no como puristas conservadores que quieren detenerse en las formas tradicionales, sino como expedicionarios por todos los dominios de las Letras y la Filosofía que aportan su magnífico botín al dominio común de nuestra familia de pueblos.

Que Pedro Henríquez Ureña, nacido en Santo Domingo, fuese figura decisiva en el movimiento mexicano de reacción anti-positiva hacia 1910; hispanista en España entre los más sabios y sagaces maestros del Centro de Estudios Históricos y profesor de gran influencia en las nuevas generaciones argentinas a partir de 1924, indica que a pesar de la fragmentación política de nuestros pueblos, disponemos de órbita inmensa para la cultura común, como quizás no pueda presentarla ningún otro linaje étnico o lingüistico. Y parecía en todas partes 
como esos humanistas viajeros del Renacimiento, cuya clara prosa y objetividad - no desprovista de amor- estaba dispuesta a desvanecer todo prejuicio, a mirar serenamente sobre toda idolatría tribal o nacionalista. A veces estos prejuicios eran pequeños disentimientos entre hermanos como el que se formó en la Argentina de fines del siglo XIX y comienzos del $\mathrm{XX}$ contra los otros países de América que no disfrutaron de la temprana ventura y opulencia de la nación austral; mitos como el del "tropicalismo" que Ios excusaba de conocer cuanto ocurría más allá de su frontera de los Andes; negación de la justicia de la revolución mexicana porque en ella se mezclaron tantos bandidos. Por una América conciliada en sus diferencias y también en sus propósitos de futuro, alega siempre Henríquez Ureña, quien había vivido y estudiado el Continente en todos los matices de lo antillano, lo mexicano, lo argentino. Nivela la tradición americana en el mensaje de sus personalidades egregias y deja en libros sintéticos como la Historia de la cultura en la América hispánica y las Corrientes literarias, el balance estimulante de esa tradición. Gran empresa que se está haciendo y no puede congelarse en las rígidas fórmulas deterministas en que se empeñó el Positivismo, era esta fundación de América. Superando el "especialismo" en que suele acorazarse todo "scholar" ( $y$ él lo era en grado máximo) se interesaba por conocer con alegre versatilidad muy latinoamericana, temas que no eran los suyos como la música y el folklore, la anécdota biográfica y el pequeño episodio político en que se refleja algo de nuestra psicología colectiva.

En el tumulto y colisión de influencias que sacudieron el espíritu occidental en los últimos cincuenta años, su instinto ordenador y su sensibilidad estética sabía encontrar la salida del laberinto. Por que no todo lo que se pone de moda o agita los círculos literarios y artísticos en determinado instante habrá de perdurar, y el papel de un crítico tan avisado es distinguir la roca pura del fangoso y embarazante aluvión. Así, en diálogos inolvidables, le veía juzgar desde las obras más significativas de la novelística contemporánea hasta aquella polémica - tan contaminada de política - que pusieron de moda los intelectuales franceses de izquierda, entre la obra de arte "gratuita" y la "comprometida". Y como siempre, en un co- 
loquio en casa de Victoria Ocampo, dijo sobre el problema las palabras más sensatas e iluminadoras. Todos los mitos, fórmulas y propagandas que lanzaba la moda o el choque ácido de las ideologías, eran juzgados y esclarecidos por su ecuánime liberalismo.

Más allá de su obra escrita, tan varia, rigurosa y rica de direcciones, hay otro Henríquez Ureña igualmente duradero: el que socráticamente dejó en la conversación, la cátedra y el diálogo de amigos, los más provocativos estímulos espirituales. Así lo recordaremos siempre, junto a la castigada prosa de sus libros, quienes alguna vez nos acercamos al generoso rescoldo de su amistad. Como su contemporáneo Alfonso Reyes, es uno de esos buenos americanos que lucharon "por el aseo de América", por el orden, claridad y exactitud en los trabajos del espíritu; por superar aquella etapa de improvisación, provincialismo y vacua verbosidad que también fueron frecuentes en nuestra cultura.

Mariano Picón Salas

Caracas, Venezuela 
